\title{
The Development of Traditional Games of Cat and Rat to Improve Social and Emotional Abilities of Children aged 5 to 6 Years Old
}

\author{
Baik Nilawati Astini* \\ Early Childhood Education Teacher Education Study Program \\ University of Mataram \\ Mataram, Indonesia \\ nilawati@unram.ac.id \\ Ika Rachmayani \\ Early Childhood Education Teacher Education Study Program \\ University of Mataram \\ Mataram, Indonesia \\ ikarachmayani.fkip@unram.co.id
}

\author{
N Nurhasanah \\ Early Childhood Education Teacher Education Study Program \\ University of Mataram \\ Mataram, Indonesia \\ nurhasanah@unram.ac.id \\ Rafiqatul Ummahaati \\ Early Childhood Education Teacher Education Study Program \\ University of Mataram \\ Mataram, Indonesia \\ rafiqafsl@gmail.com
}

\begin{abstract}
This research aims to develop traditional cat and rat games to improve social and emotional abilities of children aged 5-6 years. This research adopts the type of development research from Borg and Gall. Data collection was carried out through the observation method. Subjects in the study were 20 children. The data analysis technique used a quantitative descriptive technique. The results of the development of traditional cat and rat games in this study are the addition of aids and game rules. Some steps to play are 1) preparing the number of players, namely $15-20$ children; 2) setting up a playing field; 3) preparing the game tools; 4) explaining the steps and rules of the game; 5) children do hompimpa to determine the roles; 6) the teacher puts on the child's play equipment; 7) when they're ready, children who have not yet got the role of rats and cats form a circle as a fortress; 8) the child who acts as a rat stands in a circle and a cat stands outside the circle; 9) the child who acts as a running rat avoids the cat from being caught but both must remain within the designated area; 10) the game is over if the rat is caught by the cat and the role can be replaced by another child; and 11) the game is over if the rat or cat runs over the designated area boundaries and the role can be replaced with another child. The result of indicator achievement in first development shows that about $35.87 \%$, in second develooment indicates about $51.92 \%$, then, in third stage of development, there was a significant increase in the amount of $82.50 \%$. The development of traditional cat and rat games is one of the effective methods to improve the social-emotional abilities of children aged 5-6 years.
\end{abstract}

Keywords—traditional games, social-emotional skills, cat and rat.

\section{INTRODUCTION}

Early childhood is a very sensitive period to receive stimulation and apply it [1]. Often the early age is dubbed the developmental stage of the golden age. At this stage, children begin to develop motor, visual and auditory abilities through their surroundings [2]. The stages of growth and development of physical, cognitive, socio-emotional aspects of language and communication are being experienced in early childhood.
In addition, at this time children also experience almost all their potential, so they need to provide a good education [3].

One aspect of child development that can be developed as a provision for present and future life is the aspect of socialemotional development. This is because humans are social beings who cannot live without interaction with other humans, while the form of emotion in humans is as a representative that exists within humans themselves to express all feelings, such as sadness, joy, happiness, disappointment, angry and other feelings. Therefore, social-emotional cannot be separated because it is related to one another.

Educators are increasingly required to implement various forms of learning that support children's social, emotional and behavioural development [4]. According to Hurlock [5] social development is the acquisition of the ability to behave in accordance with social demands. Meanwhile, Erik Erikson sees the ability of social development in children related to their ability to overcome crises or conflicts that occur at each stage shift so that they are ready to face all kinds of problems that will be encountered in their next life.

Social-emotional development or enhancement of children at an early age is very important for future developments such as developing a confident attitude towards others and oneself, being able to control biological impulses and learning to adapt to society, developing an understanding of social behaviour, learning to adapt behaviour with the demands of the environment, learn to understand the perspectives (views) of others and respond to their expectations/opinions selectively [6].

In addition to the role of parents in the family environment, the role of teachers in the school environment is also a factor that is no less important in stimulating children's socialemotional development, this is because school is a second home for children to get stimuli that can help develop their social-emotional aspects. The problem that arises is the lack of stimulus and methods from schools to develop socialemotional aspects of early childhood due to the lack of knowledge and creativity of teachers and schools about what 
media and how to develop these social-emotional aspects. In fact, Indonesia itself has very diverse potentials. Traditional games for example, every region in Indonesia must have its own traditional games. These games usually have to be played in groups which of course can help develop the socialemotional aspect of the child and use simple rules.

Traditional games are games that develop and are played by children in the general public by absorbing all the wealth and wisdom of their environment [7]. Traditional games make people who play them skilled, nimble, and agile [8]. In addition, traditional games which are designed as learning media, it can facilitate various social-emotional developments [9]. Educators should choose games that are in accordance with environmental conditions and goals to be achieved, especially for child development [1].

Based on the explanation of the problem above, the researcher tries to provide a solution by introducing one of the results of the development of traditional games that are well known in Indonesia, namely the traditional game of cat and rat. This game has existed since ancient times and is played in groups by children in an open field or a wider place. Researchers hope that through this game children can make it a medium to develop their social-emotional aspects. Because it is played in groups, of course, children indirectly have to interact with their playmates. The agreed simple rules are expected to provide lessons and norms that apply in the child's life.

\section{METHODS}

This development research used a research and development model adapted from the Borg \& Gall model. This research was conducted in 3 stages of development. Each development stage has a planning, implementation, and reflection stage then three times reinforcement at the final development stage (third development). Subjects in this study were 20 children aged 5-6 years at a kindergarten in Mataram City. Data collection techniques were carried out through observation with validated instrument sheets. The data analysis technique was analyzed using quantitative descriptive techniques. For data interpretation problems and needs using the criteria in Table 1 below.

TABLE I. LIKERT SCALE FOR ASSESSMENT OF CHILDREN'S SOCIALEMOTIONAL DEVELOPMENT

\begin{tabular}{clcc}
\hline No. & Level of Development & Code & Score \\
\hline 1. & very well developed & BSB & 4 \\
\hline 2. & well developed & BDB & 3 \\
\hline 3. & Start to develop & MB & 2 \\
\hline 4. & undeveloped & BB & 1 \\
\hline
\end{tabular}

\section{RESULTS AND DISCUSSION}

Children's social development is obtained from maturity and learning opportunities from various environmental responses to children [10]. Meanwhile, emotional development in children is marked by the emergence of pride, shame, and guilt. The emergence of these emotions shows that the child has understood the prevailing social norms and assessed their behaviour [11]. In this study, a traditional game of cat and rat was developed to improve children's socialemotional abilities.

From the results of the development research that has been carried out, the results obtained from development I to development III, namely the traditional form of cat and rat games which do not have fixed rules and are free to be played by any number of children, are still played in groups but are limited to a minimum of 15 and a maximum 20 children. This aims to make the division of roles easier to do. In addition, the circumference of the fort is not too small so that the running range of the children who act as cats and mice is wider. The development was also carried out by providing additional tools in the form of cat and rat ears. The tool is used to make it easier for players to differentiate between roles. This was done because it seemed that the children still had difficulty focusing when immersed in the game, so they often confused which players should be protected from being chased by other players. Development is also carried out on the steps and rules of the game by adding a running boundary to make it easier for players. Playtime is also minimized so that more children get a role in a short timeframe and can be adjusted according to break times or before entering class.

In this cat and rat game, several rules of the game must be followed before starting the game. The rules of the game in the traditional cat and rat game include: (1) the children are divided into one group of 15-20 children, (2) the division of roles is carried out through self-show or hompimpa if during the game there will be many children who want to get a role, (3) the child must finish the game until it is finished and accept the role division turn, (4) the child who gets the role of cat and rat must not run across the boundaries of the area. If this is done, then the child who violates the rules is declared defeated and must change roles. As for the development of steps that have been adjusted to the level of achievement of the development of social emotional abilities of children aged 56 years, are: (1) dividing the role of children into cats, rats, and rats (2) children who get the role of cats and mice wearing aid accessories in the form of a bandana in the form of cat and rat ears (3) children who act as a fort stand hand in hand with a combination of girls and boys standing intermittently, women and men (4) before the game takes place, the rats first stand in a circle and cats waiting outside the circle. (5) the game begins when a signal from the teacher is called. (6) the cat is in charge of chasing mice and rats must try to escape with the help of the fort as a barrier. (7) the game is over when the cat catches the rat or the child who plays the role of running out of the boundary of the running area. 


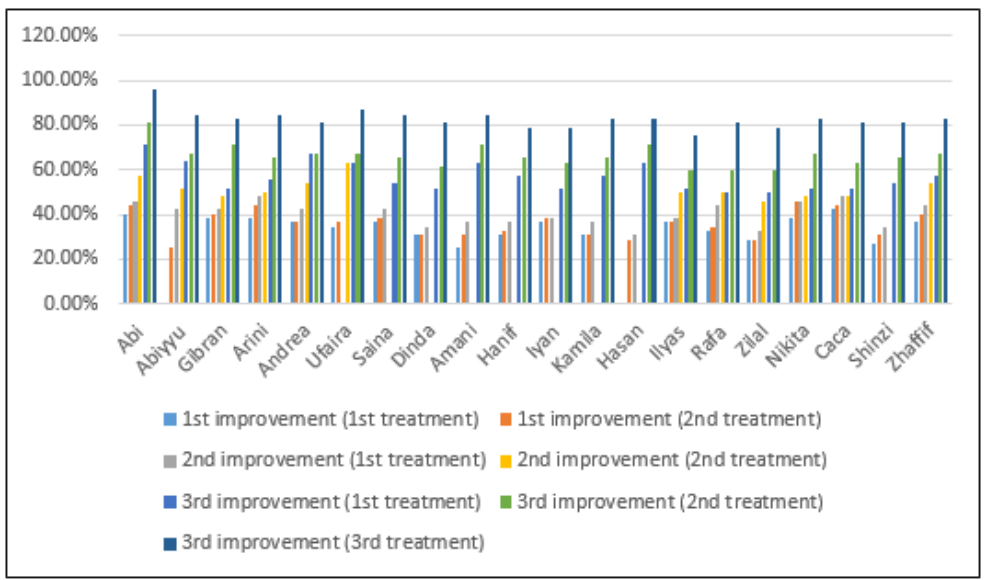

Fig. 1. Achievement of Child's Social-emotional Aspect Indicator Development

At the time of the research, the children appeared to have no respect for each other's rights, obligations, and roles. It was proven that at the beginning of applying the traditional game of cat and rat, two children even refused to participate in the game even though they had agreed to play together. Before the game took place, the children were still arguing to get the role even though the roles had been agreed upon and this was quite an obstacle to the playing of the game. But as time goes by and children get to know the rules of the game, children can wait and carry out their respective roles because they understand that all children will get their rights if they play according to the rules and agreements that have been agreed upon and will lose their rights if they violate. After applying the games that have been developed and providing guidance, it can be seen from the graph that the social-emotional abilities of children aged 5-6 years have increased and this is in line with previous research conducted by Nurmalitasari [10]. The social-emotional development of children aged 5-6 years can be seen from their ability to play in groups. The characteristic at this stage is that children begin to know the rules around them, then they begin to comply with these rules, then children begin to realize the importance of these rules, only then do children realize the importance of the rights of others, and they begin to be able to play with their peers.

From figure 1, it can also be seen that the average results of children's indicators in each stage of development and treatment continue to increase. The results of the first development (treatment I) only reached an average value of $28.84 \%$ and treatment II reached $35.87 \%$ so that the researchers felt the need to develop more rules and stages of playing cats and rats. Then in the development stage II of treatment I, the researcher got a result of $40.38 \%$ which indicated that the development was still at the stage of starting to develop and in treatment II it reached $51.92 \%$. In the third stage of development of treatment I, the average indicator of children reached $57.12 \%$. At this stage, the researcher discussed with the teacher and decided to do repetition as reinforcement to find out whether the traditional game of cat and rat needs to be developed again or not. However, it turns out that in the development III of treatment II and III the researcher got an average result of indicators which continued to increase rapidly, namely as much as $66.25 \%$ and the final result of $82.50 \%$. This proves that in development III, the average child indicator increases the most rapidly.
Researchers get an average percentage increase from development I to development III treatment III of 53.66\%.

Based on the results obtained, it can be seen that the traditional game of cat and rat can be used as a method of developing the social-emotional abilities of children aged 5-6 years. It can be seen from the increase in the achievement of children's ability indicators which indicate that the socialemotional development of each child also continues to increase and the child's behaviour towards their environment has changed quite significantly. Such as children who begin to be able to respect their peers or adults around them when talking, children who start playing without distinguishing certain groups, children who can congratulate their friends who win the game and do not mock their friends who lose the game, etc. This is in line with research by Rahayu [1] which shows that traditional games can be used as a method to improve the social-emotional abilities of children aged 5-6 years. Traditional games that are applied to early childhood can also form character [12] and as a means of stimulating their development [13].

Emotional abilities are important to improve. Rhoades et al [14] stated that children's socio-emotional knowledge needs to be considered because it will also have an impact on the improvement of children's academic competence. Socialemotional development in children will play an important role in the future to support their academic achievement [15]. In addition, social-emotional abilities are also considered important for screening early childhood with special needs [16].

\section{CONCLUSION}

Based on the results of the research that has been done, it can be concluded that the development of traditional games can be used as a method to develop the social-emotional abilities of children aged 5-6 years. There is an increase in the achievement of children's ability indicators which indicate that the social-emotional development of each child also continues to increase and the child's behavior towards their school environment has changed quite significantly. Children begin to appreciate peers or adults around them when talking, children who start playing without distinguishing certain groups, also children who can congratulate their friends who win the game and do not mock their friends who lose the game. 


\section{REFERENCES}

[1] D. I. Rahayu, N. Nurhasanah, and I. N, Suarta, "Penerapan Permainan Tradisional Pada Main Pembukaan Pembelajaran Anak Usia Dini," Indonesian Journal of Elementary and Childhood Education, vol. 2, no. 1, pp. 171-176, 2021.

[2] D. H. Schunk, Learning Theories An Educational Perspective TeoriTeori Pem-belajaran: Perspectif Pendidikan (Edisi keenam). Yogyakarta: Pustaka Pelajar, 2012

[3] R. W. Anzani, and I. K. Insan, "Perkembangan Sosial Emosi pada Anak Usia Prasekolah,” PANDAWA, vol. 2, no. 2, pp. 180-193, 2020.

[4] B. D. McLeod, K. S. Sutherland, R. G. Martinez, M. A. Conroy, P. A. Snyder, and M. A. Southam-Gerow, "Identifying common practice elements to improve social, emotional, and behavioral outcomes of young children in early childhood classrooms," Prevention Science, vol. 18, no. 2, pp. 204-213, 2017.

[5] E. B. Hurlock, Child growth and development. Tata McGraw-Hill Education, 1978.

[6] L. D. Ismayanti, Pengaruh Permainan Tradisional Engklek (Sorok Dan Payung) Terhadap Peningkatan Kontrol Diri Pada Anak Usia Sekolah Dasar (Doctoral dissertation, University of Muhammadiyah Malang), 2017.

[7] N. Mulyani, Super Asyik Permainan Tradisional Anak Indonesia. Yogyakarta: DIVA Press, 2016.

[8] B. Y. Wulansari, “Pelestarian Seni Budaya Dan Permainan Tradisional Melalui Tema Kearifan Lokal Dalam Kurikulum Pendidikan Anak Usia Dini,” JURNAL INDRIA (Jurnal Ilmiah Pendidikan Prasekolah dan Sekolah Awal), vol. 2, no. 1, 2017.

[9] A. Mukhlis and F. H, "Analisis Perkembangan Sosial Emosional Anak Usia Dini Pada Permainan Tradisional. Preschool," Jurnal
Perkembangan dan Pendidikan Anak Usia Dini, vol. 1, no. 1, pp. 1128, 2019.

[10] F. Nurmalitasari, "Perkembangan sosial emosi pada anak usia prasekolah. Buletin Psikologi," vol. 23, no. 2, pp. 103-111, 2015.

[11] W. J. Santrock, Perkembangan Anak. Jakarta: Erlangga, 2007.

[12] O. Witasari and N. A. Wiyani, "Permainan Tradisional untuk Membentuk Karakter Anak Usia Dini," JECED: Journal of Early Childhood Education and Development, vol. 2, no. 1, pp. 52-63, 2020.

[13] H. Munawaroh, "Pengembangan model pembelajaran dengan permainan tradisional engklek sebagai sarana stimulasi perkembangan anak usia dini," Jurnal Obsesi: Jurnal Pendidikan Anak Usia Dini, vol. 1, no. 2, pp. 86-96, 2017.

[14] B. L. Rhoades, H. K. Warren, C. E. Domitrovich, and M. T. Greenberg, "Examining the link between preschool social-emotional competence and first grade academic achievement: The role of attention skills," Early childhood research quarterly, vol. 26, no. 2, pp. 182-191, 2011.

[15] W. T. Gormley Jr, D. A. Phillips, K. Newmark, K. Welti, and S. Adelstein, "Social - emotional effects of early childhood education programs in Tulsa," Child development, vol. 82, no. 6, pp. 2095-2109, 2011.

[16] R. D. Briggs, E. M. Stettler, E. J. Silver, R. D. Schrag, M. Nayak, S. Chinitz, and A. D. Racine, "Social-emotional screening for infants and toddlers in primary care," Pediatrics, vol. 129, no. 2, pp. e377-e384, 2012. 